\title{
An Essay in Comparison: Shakespeare's Technical Inventiveness in the Light of George Puttenham's Arte
}

Catherine Lisak

\section{(2) OpenEdition \\ 1 Journals}

\section{Electronic version}

URL: http://journals.openedition.org/shakespeare/800

DOI: 10.4000/shakespeare.800

ISSN: 2271-6424

Publisher

Société Française Shakespeare

\section{Printed version}

Date of publication: 1 November 2002

Number of pages: 125-141

\section{Electronic reference}

Catherine Lisak, "An Essay in Comparison: Shakespeare's Technical Inventiveness in the Light of George Puttenham's Arte ", Actes des congrès de la Société française Shakespeare [Online], 20 | 2002, Online since 01 November 2007, connection on 22 April 2019. URL : http://journals.openedition.org/ shakespeare/800; DOI : 10.4000/shakespeare.800 


\section{S H A K E S P E A R E \& S E S \\ C O N T E M P O R A I N S}

Société Française Shakespeare

Actes du Congrès de 2002

$* * *$

Textes réunis et présentés par

Patricia DORVAL

publiés sous la direction de

Jean-Marie MAGUIN 


\section{A N ESSAY IN COMPARISON : SHA K E S PEARE' $S$ 《T ECHNICAL INVENTIVENESS》IN THE LIGHT OF GE.ORGE PUTTENHAM'SARTE}

When E.A.J. Honigmann brought out a collection of «essays in comparison», under the general heading of Shakespeare and his Contemporaries, in 1988, his purpose was to show that «much can be gained by not dividing Shakespeare from the others», something which was too often the case, he remarked, «because it is thought that this is what teachers or publishers demand». He thus invited contributors to «select two plays that appear to be connected in their handling of technical problems», in order to «re-examine the technical inventiveness of Elizabethan dramatists». "The thread that holds the book together is our conviction that the innovative skills of the Elizabethans - and of Shakespeare - were more diversified than is commonly assumed»'. His volume of essays concentrated on the compared artistry of dramatists in their craftsmanship and creative handling of verse, prose and stage conventions. Restricting the field of comparison to dramatists was in keeping with the edition of The Revel Plays series, to which the volume was conceived as a follow up. Though the title of this collection of essays does encourage scholars to conduct further research around the manifold links that transpire between Shakespeare and his contemporary authors, 
beyond the canon of dramatists of the period. Indeed, in one of the essays, which offers a comparison between Doctor Faustus and Macbeth, Kurt Tetzeli von Rosador first feels the need to contextualize on a grander scale, as he looks towards general Elizabethan ideas on perception, and on the concept of diabolical or magical interference, in order to shed light upon the process of temptation that commands the actions of both eponymous protagonists. This leads him, as if perforce, to glance at George Puttenham's interpretation of the functioning of imagination ${ }^{2}$. The critic's approach, at this point, presents the special interest of reading Puttenham to throw light upon those dramatists like Shakespeare who, as is most often taken for granted, made use of this manual on poetics. Frequently, in studies of this sort, Puttenham is profusely quoted and analyzed, though he appears in parallel to analyses on Shakespeare, Castiglione, or other contemporaries, rather than in relation to them ${ }^{3}$. For instance, in Frank Whigham's remarkable exploration of courtesy literature, Ambition and Privilege: The Social Tropes of Elizabethan Courtesy Literature ${ }^{4}$, one sees how Puttenham becomes a focal point of study and how his figures of speech are examined in intricate detail, from «affectation», «allegoria», «cosmesis» and «paradiastole», to certain concepts, such as «decorum», «deceit» or «self-trivialization». Though Shakespeare regularly receives mention over similar topics, in following lines or surrounding pages, both authors appear in juxtaposition, rather than in relation, one to another. The possible associations between dramatist and theorist were not, to be sure, Frank Whigham's purpose ; they beckon, nonetheless, to be made in a more rigorous and systematic fashion than has hitherto been done. One does, indeed, come across sporadic comparisons between both authors, interspersed within the manifold editorial notes on Shakespeare's plays. To take only one example, commonly found in most editions of King Lear, an obvious proximity has been shown to exist between the fool's prophetic lines in III.2.80-93, and verses found in Puttenham's Third Book, «Of Ornament», which are in fact lines taken from Geoffrey Chaucer. It would seem that Shakespeare's rewriting of these lines were a parodic interpretation of Puttenham's own quotation and analysis of Chaucer".

In fact, there seems to have been only one attempt, yet unequalled, to understand the close and complex connections recognizable between Shakespeare and Puttenham's manual, a meticulous study in comparison by William Lowes Rushton broached in his Shakespeare and 'The Arte of English Poesie', ${ }^{, 6}$ which dates back to the beginning of the twentieth 
century (1909). In his opening page, the author justified his effort to find some intricate links between both authors by suggesting: «knowledge of this old book, with which Shakespeare was very familiar, has enabled me to illustrate many obscure passages and words and expressions of doubtful meaning. Shakespeare not only introduces in his Plays many Figures which Puttenham describes, but he also frequently uses the same words which appear in the examples Puttenham gives of the Figures» ${ }^{7}$. As a result, throughout his work, Rushton picks out specific words, which occur only once, both in Shakespeare and Puttenham, such as the word «inhabitable» (in Shakespeare, Mowbray would meet Bolingbroke in duel «Even to the frozen ridges of the Alps, / Or any other ground inhabitable», and in Puttenham : «Henry the Eight made spoils in Turwin, when as in deede he did more than spoile it, for he caused it to be defaced and razed flat to the earth, and made it inhabitable») ${ }^{8}$. Or else Rushton quotes several lines or whole passages from Shakespeare, to show that the playwright had in mind a section in the Arte, very close in structure, vocabulary and gist to the dramatist's lines. W.L. Rushton's work thus boils down to a listing of convincing parallels between Shakespeare's plays and Puttenham's Arte, on the basis that the one would seem to echo the other, and that Shakespeare would clearly have read Puttenham and had a particular passage in mind when using a particular figure of speech or word. In so doing, Rushton identifies no less than thirty-five possible links. Unfortunately, his discoveries do not lead him for as much to a particular understanding of the way Shakespeare makes use of Puttenham - either of the dramatist's interpretation of the Arte, or of his strategies and purposes in handling such material. All in all, he never goes beyond the stage of a disconnected compilation of comparisons, a desultory cataloguing of findings, based on no thorough line of argument to guide us along other than the actual tracing of similarities and coincidences, as he plainly states, and repeats with each finding, that Shakespeare had specific passages of The Arte in mind when he wrote lines of his own. Consequently, his intriguing and appropriate detections still sorely cry out for analysis and conceptualisation. His work contains ample matter for thought, though it stands more as a rough work, the starting point of a study that never saw the day. For instance, if Shakespeare only uses the word «spire» once, in the same way as Puttenham does, to signify a leader's greatness (Coriolanus's in Shakespeare's play, Queen Elizabeth's, in Puttenham's work), or if he makes use of the unusual meaning of «circumstance», to signify «words» (in Much Ado About Nothing, V.1; 
King Richard III, I.2 ; Hamlet, III.1 ; and The Comedy of Errors, V.1) as does Puttenham (when defining «Allegoria» or «false semblant»), it might be said that Shakespeare found the unstable and ungoverned meaning of words, as intimated in The Arte, most appealing and challenging to the dramatist's pen : all this requires in depth investigation. It is, therefore, with this given basis of William Lowes Rushton's work, and the «parti pris» shared with Honigmann - that Shakespeare gains to be studied with his contemporaries in mind - that this comparative essay proposes to offer greater insight into Shakespeare's handling of Puttenham. This paper will attempt to identify several of Shakespeare's many strategies as a dramatist, which transpire as he considers the vaious poetical problems raised by Puttenham in The Arte of English Poesie (1589)', though in the process, we will discover that he tackles these issues by branching off from Puttenham's restricted applications of rhetorical rules, and by granting these stylistic complexities greater scope of meaning. The paper will pick out three instances suggested by Rushton - the study of «surplusage», of «rascal» as a word, and of «metaphora» - as illustrative of the fact that Shakespeare borrowed from Puttenham, and analyse the technical inventiveness at work within Shakespeare's lines, as intimated by Rushton's most plausible, yet unexplored comparisons.

William Lowes Rushton first draws our attention to Puttenham's definition of the figure of speech called «surplusage», and to the example offered to illustrate his point. He also successfully identifies the various occasions in which Shakespeare uses the same phrasing as the one encountered in Puttenham's text. His analysis, in Book III, chapter XXII (the title runs : «Some vices in speaches and writing are alwayes intollerable, some others now and then borne withall by licence of approued authors and custome» - which, as we shall see, is not without significance) runs as follows :

Also the Poet or makers speech becomes vicious and vnpleasant by nothing more than by vsing too much surplusage : and this lieth not only in a word or two more than ordinary, but in whole clauses, and peraduenture large sentences impertinently spoken, or with more labour and curiositie than is requisite. The first surplusage the Greekes call Pleonasmus, I call him [too full speech] and 
is no great fault, as if one should say, I heard it with mine eares, and sawe it with mine eyes, as if a man could heare with his heeles, or see with his nose. We our selues vsed this superfluous speech in a verse written of our mistresse, neuertheles, not much to be misliked, for euen a vice sometime being seasonably vsed, hath a pretie grace,

For euer may my true loue liue and neuer die

And that mine eyes may see her crownde a Queene.

As, if she liued euer, she could euer die, or that one might see her crowned without his eyes.

Rushton locates three occurrences of the specific surplusage «I heard it with mine eares, and sawe it with mine eyes» in Shakespeare, which he considers were written with Puttenham's paragraph in mind. These are (1) the nurse's frantic line : «I saw the wound, I saw it with mine eyes», in Romeo and Juliet (III.2.52) ; (2) Pistol's answer to Falstaff's summoning of his attention in The Merry Wives of Windsor: «He hears with ears» (I.1.134), and (3) in the final line of Sonnet 23 : «To hear with eyes belongs to love's fine wit»". Rushton's analysis becomes, from this moment onwards, threadbare, though the links he establishes between both authors are most revealing and potentially rich in significance :

The nurse uses the exact words, "saw it with mine eyes,' which Puttenham uses in illustration of this Figure, and Pistol and Evans use the words, 'hears with ears.' Evans confuses surplusage with Fond affectation; he seems to think that Pistol affects a new phrase other than custom or the good speakers and writers in any language have allowed, and that he makes use of the intolerable manner of speech which Puttenham calls «Fond Affectation».'

It would first be interesting to consider, how these three very different, yet very close, verbal parrallels link up, to testify to Puttenham's being Shakespeare's direct source. One notes that the two characters, the nurse and Pistol, who have recourse to this «superfluous» form of speech, are low-ranking commoners ; as a result, their general handle of the English language makes surplusage appear as an «intollerable» figure of speech, suggestive of gaucherie rather than of any applied artistry on their behalf : hence Sir Hugh Evans' reaction (I.1.134-6), as also Juliet's, a few lines 
earlier, as she underscores her nurse's lack of tact : «What devil art thou that dost torment me thus ?» (III.2.43). The figure of surplusage here serves to emphasize the characters' general awkwardness and comical traits : namely the nurse's fundamental garrulity, which shows her off as emphatically coarse and cruel, for despite her tautological assertion, she still manages to instill confusion and ambiguity (as to who has been killed, instilling fear needlessly in Juliet, so that, to some extent, tragedy and comedy battle it out at this stage), all of which are forms of some «intollerable» speech, as defined in Puttenham's chapter. The same rhetorical device seems similarly, yet appropriately insufferable when Pistol pretentiously yet unsuccessfully attempts to sound erudite and scholarly, blurting out single-line quotations, all unfailingly misquoted, from Doctor Faustus - «How now, Mephostopilus ?» (I.1.119), or from the Bible - «He hears with ears» (the original line being «We have heard with our ears», Psalms $44: 1)^{13}$. The surplusage becomes all the more «impertinent» - that is to say, both inappropriate and affected - as the personal pronoun «I» grows into an inflated third person «he». Like Master Slender and Mistress Quickly, his efforts to reproduce the language of proverbs and clichés turn out to be poor performances, for he trips up systematically. Ironically, this makes his intolerable speech become tolerable, because comical and entertaining, simply verging on the meaningless, though the ridicule is good-humoured and welcome. Hence, what has been said of Puttenham could also be said of Shakespeare, that he does not dissociate the literary concept from its social application ${ }^{14}$. As it is here used, surplusage reflects a certain popular handling of culture and language, and evolves from an intolerable to an agreeable form of speech, its meaning being dictated by the comical setting within which it occurs.

Of course, this comical situation is heightened by Sir Hugh Evans, who picks up on Pistol's «surplusage», and offers a stylistic criticism that echoes back to Puttenham's own study of «intollerable speech», though his remarks seem more in keeping with what is said in a paragraph or so before, on «Cacozelia» or «Fond Affectation», than with the concept of «surplusage» itself : "The tevil and his tam! What phrase is this? 'He hears with ear'! Why, it is affectations» (I.1.134-5). Instead of designating the speech as «impertinent» or «superfluous», he talks of there being «affectation» on Pistol's part, a comment that could boil down to the same thing as surplusage, though in Puttenham's chapter the word refers to a slightly different form of «intollerable speech» : 
Ye haue another intollerable ill maner of speach, which by the Greekes originall we may call fonde affectation, and is when we affect new words and phrases other then the good speakers and writers in any language, or then custome hath allowed, \& is the common fault of young schollers not halfe well studied before they come from the Vniuersitie or schooles, and when they come to their friends, or happen to get some benefice or other promotion in their countreys, will seeme to coigne fine wordes out of the Latin, and to vse new fangled speaches, thereby to shew themselues among the ignorant the better learned.

Certainly «tam» and «tevil» could not be described as words good speakers or writers could allow. And «good worts» as an interpretation of «Pauca verba» (I.1.111) is a translation not even Falstaff can let pass. The irony contained in Evans' comments on «He hears with ear» is born from the fact that, in wanting to denounce Pistol's ignorance and insolence, he in fact points the finger to his own manner - and mismanagement - of speech. Though Evans would derive his authority from his honorary title as a parson, and be the mouthpiece of eloquence and style (see his indignation at Bardolph's linguistic ignorance, and his congratulating Slender's happy choice of words), his authority is deflated, as his rhetorical analysis makes him join the Pistols and Bardolphs of this world, of whom it is not at all expected that they «should be verbal and grammatical precisians» ${ }^{16}$, as Gladys Willcock and Alice Walker remark in their introduction. In effect, for the beginning of this first scene of The Merry Wives of Windsor, Shakespeare makes his character talk in figures of speech that correspond exactly to those ill-formulations and «intollerable speeches» which Puttenham would at all times condemn, and which one finds listed within the first part of chapter XXII. Thus, Evans commits a «Barbarismus or Forrein speech», which ranks tops as «the foulest vice in language [...], as he that would say with vs in England, a dousand for a thousand, isterday, for yesterday, as commonly the Dutch and French people do» - and, so it would seem, the Welsh : a «'orld» for «world»; «Got» for «God»; «pless» for «bless»; «fery» for «very» the list is endless, for Evans' pronunciation is at the bottom of his corruption of words, or, «worts», as he would have it; he makes, indeed, no difference between $« \mathrm{~d} »$ and $\langle\mathrm{t} »,\langle\mathrm{p} »$ and $\langle\mathrm{b} »,\langle\mathrm{f} »$ and $\langle\mathrm{V} »$. What's more, 
Evans' speech is riddled with «Solecismus or Incongruitie», the next intollerable speech on Puttenham's list - «as when we speake false English, that is by misusing the Grammaticall rules to be observed in cases, genders, tenses and such like, euery poore scholler knowes the fault», as Evans himself testifies : «It is spoken as a Christians ought to speak» (I.1.92). His speech also contains such linguistic mishaps as a «Soraismus or the mingle mangle», which he seems to emulate, onomastically : "It were a goot motion if we leave our pribbles and prabbles» (I.1.50); and one also encounters «Cacosintheton or the Misplacer», that is the ill disposition of a word, clause or sentence : «Therefore, precisely, can you carry your good will to the maid?» (I.1.211) ". Evan's speech seems to apply every shape of unforgivable intollerable speech as denounced by Puttenham, as if Shakespeare had chosen this character as the mouthpiece to Puttenham's study at the beginning of chapter XXII, and was plunging into Puttenham's list of impardonable mistakes, giving them voice, one by one, through Evans' repartees. There is an amused «clin d'œil» on behalf of the poetplaywright, who has his characters teach language to the audience, often with ironical, derisory assurance. At times such lines seem to recall Puttenham's own urbanely self-confident tone that runs through The Arte, as if Shakespeare were for a moment parodying the very author of the manual. It might be said that Shakespeare, tongue in cheek, seems to be using poetry as Puttenham would have understood it, by consciensciously running through the most technical of Renaissance surveys of linguistics within poetry and drama, though his own interpretation would be adding a slant.

Surplusage, in comparison, belongs to that second category of illchosen words or phrases, which can be as «intollerable» as they can have «pretty grace» when appropriately used. And it is around the redemptive theme of love that Puttenham demonstrates this point, by quoting two lines of his own. Similarly, in Shakespeare's Sonnet 23, the surplusage is not coarse ; on the contrary, it is "seasonably» used to underline love's sharpened insight. It also reveals the dramatist's vivid pleasure taken in underscoring the twist of logic following the way one applies the turn of phrases to a situation. Shakespeare seems to be stretching Puttenham's initial analysis to the limit, applying twists and turns to the interpretations and illustrations advanced, showing off the fundamental plasticity of such a text, when that text is a manual, to be handled and toyed with vertuosic prowess, outdoing the initiator in his juggling with words and meanings, 
with contexts and interpretations of idioms. It transpires, without doubt, that Shakespeare had read Puttenham closely, and was sensitive to the variations in meanings Puttenham studied in his choice of quotations or particular words. Puttenham's examples were as much exploited by the dramatist, when applying the specific figure of speech it illustrated to a dramatic piece of his own, as the definitions themselves. Turning the intollerable into a recreational piece, a solace to man's wit, was one of Shakespeare's ways of reading Puttenham and making use of his teaching : for in the dedicatory paragraph, written by Richard Field, it was specified that The Arte was a text designed to entertain her Majesty as much as to instruct her. Shakespeare seems to have followed Puttenham in his path to combine the serious with the distractive and amusing. $\mathrm{He}$ shares in his understanding of the potentially manifold meaning and handling of words, unorthodoxy not implying the harming of poetry in any way, nor its debasement, quite the contrary in fact. So that, what Gladys Willcock has said of Puttenham, as she presents his credo as a critic, could very well apply to Shakespeare's own approach to poetic drama: «To admit trifles or careless mirth into the ample scope of poetry was not to make Art itself trifling or careless» ${ }^{18}$.

That Shakespeare seems as receptive to Puttenham's examples as to the definitions they serve to illustrate is relatively easy to point out. For instance, to illustrate the «figure of Abuse» called «Catachresis», Puttenham offers the following mise en scène of a dialogue : «as one should in reproch say to a poore man, thou raskall knave, where raskall is properly the hunters term given to young deere, leane \& out of season, and not to people»". Rushton notes that the word "rascal» is used twice in Shakespeare's Histories, and is both times closely associated to the idea of leanness or thinness. In Henry IV Part 2, Doll Tearsheet exclaims : «Come, you thin thing; come, you rascal !» (V.4.30) ${ }^{20}$. Similarly, in The First part of King Henry VI, Alençon brags : "One to ten! / Lean raw-boned rascals !» (I.1.34-5) ${ }^{21}$. In both instances, Shakespeare combines the proper usage of the term «rascal» (that is to say the thinness of deer too young to be hunted) to its figurative meaning as a mild word of abuse. He exploits the linguistic richness pointed up by Puttenham to the full, making both levels of meaning function simultaneously. Such an example goes to show how Shakespeare enjoys - there is, indeed, an undeniable element of playfulness on his part - applying a figure of speech as defined in the handbook for poets while simultaneously showing off its mechanisms through puns, shifting back and forth between the literal meaning and the 
figurative. Like Puttenham, the dramatist understands how to adjust poetry to the variety of human situations and experiences and, most importantly, he shares in Puttenham's sense of humour, by welcoming the idea that one may successfully «misuse» the English language, thanks to poetic forms and figures.

This intertextuality between Shakespeare and Puttenham may take on a more complex shape, as it incurs reversal of meaning or intent. To better appreciate Shakespeare's degree of technical inventiveness in the use he makes of Puttenham's paragraphs, let us compare the Prologue of Act II from Henry $V$, taken in its entirety (text 1$)^{22}$, with Puttenham's intricate study of «Metaphora», Book III, chapter XVI (text 2). To begin with, we turn, with Rushton, to the most obvious parallels : «digest», «abuse», and «transported» are three words which, in Shakespeare's text, follow closely, echoing Puttenham's same words and word order as he describes the way in which metaphora works. The word «digest» is «wrested from its rightful meaning» : if one cannot digest words, meaning one cannot absorb the offence, in Puttenham's text, Shakespeare makes use of the transposition of meaning, applying, as a dramatist, the digestion not to words, but to his play as a whole, and more particularly, to the very representation of a play: hence follow such expressions as "We'll not offend one stomach with our play», and the phrase «force a play» (J. Dover Wilson underlines the culinary meaning of the word «force», designating «stuffing» or «farce» - forced comedy ?). Added to this, one notices that a succession of various «Metonimies, or figures of transport» appear in Shakespeare's text, as listed in Puttenham's treatise : one encounters in order Personification («Expectation», «England» and «France»); the figure of abuse or Catachresis ( «all the youth of England are on fire»; «a nest of bosoms») ; the figure of Metonimia, a misnamer or cross-namer, «as when we call love by the name of Venus» (here the messengers become «Mercuries»); Antonomasia, Surnamer or new naming («fearful France») ; Onomatopeia, New namer or change of name («And thence to France shall we convey you safe»: the whistling and sibilant consonants and fricatives express stealthy movement indeed).

But more than simply applying the rules as given in the chapter, Shakespeare plays with the meanings of each word, giving yet a new multiplicity of meanings and producing different effects from those in The Arte. He does indeed at times apply Puttenham's definitions to surreal extremes : «transport» is taken away from its figurative, metaphorical sense, and dragged back to its fundamental significance, to be understood 
literally as a physical removal from one geographical point to another, as the chorus invites us to change scenes, and even transports us to different counties and countries, inviting us to travel - in our imagination - from one setting to another, from London to Southampton. This spatial displacement is at all moments possible because «transport» remains a simple operation of the mind, of our imagination, as Puttenham suggests in «now must the mind also be served»: this is what Shakespeare has been attempting to do by interpreting the word both figuratively and literally. Transportation is from then on expressed in every possible way: «convey», «shift», «take ship from», «set from», «bring back to», «give pass». And just as it is to be understood in its most literal sense, it also takes on the metaphorical meaning of treason: it links up with such meanings as «divert», «treacherous crowns fill hollow bosoms», and treason itself is transported onto the stage to thrive in all shapes and forms : «intelligence», «corrupted treasons», «treacherous» and «traitors». Other echoes can be identified, which reveal an inversion or reversal of meaning from Puttenham's initial text: the crown, which according to Puttenham is the «highest ornament of a Princes head», can be compared to those «crowns imperial, crown and coronets, / Promis'd to Harry and his followers» which have progressively turned into «treacherous crowns» in Shakespeare's lines. That which metaphorically would «crown a hill or a tree» in Puttenham now crowns «hell and treason» in this Prologue. More inversions are yet discernable : whereas in Puttenham's text, the man of law «had not his fee in his hand», the chorus on the contrary confidently states «The sum is paid»; unlike Puttenham's example, in which it is said «I cannot digest your unkinde words», Shakespeare's audience will not have its «stomach offended with the play». If, in Puttenham's suite of examples, another man yet complains to an Advocate, saying "Why barkest thou at me so sore ?», Shakespeare will see to it that «the traitors are agreed»; there is not a sense of dissention as in Puttenham's text, but then again, these are not men of law.

Shakespeare makes «metaphora» operate as a figure of speech in every possible manner ; inversions thrive, not only between the literal and the figurative, but from the lawful to the corrupt, that is from one system to its opposite ; reversals constantly occur as one passes from Puttenham's to Shakespeare's own lines, which appear as so many variations composed around Puttenham's first motif : Shakespeare has used Puttenham's text as a sounding board as well as a tramplin to write the Prologue in a gloriously metaphorical style. That is why Shakespeare's technical inventions are 
better gauged when read with Puttenham's initial text at hand. The multiple inversions, reversals, variations, modifications, shifts of meaning and imagery, deviations and declensions of significances, transpositions all become rhythmical and melodious, as they are brought to light by a comparative study between these two authors. The tour de force is when the figure of speech informs the actual theme of treason itself, born of artifice, of Art ; and Puttenham wrote his third book demonstrating that there was an art to treason, and that all artists were intrinsically and metaphorically the epitome of traitors. The composition of the whole Prologue is thus informed with a single theme of Transport repeated, altered and embellished, as in music, as in some biological process as well, where one would be witnessing a metamorphosis taking place from text to text, as there occurs a marked deviation in Shakespeare's Prologue from the typical form or function of Puttenham's demonstrative chapter. Shakespeare's piece of writing is that of a consummate master of poetical and theatrical techniques who takes pleasure in showing off his dazzling skills of interpretation of Puttenham's manual. A more thorough and intricate reading of Shakespeare's plays in this light would inevitably lead criticism to new insight as to the way in which Shakespeare wrote and composed the manifold speeches and dialogues of his plays. This is an enterprise that has only just begun and deserves to be pursued.

Catherine LIS AK Université Bordeaux III 


\section{King Henry $V$, Act II}

\section{Enter Chorus}

Now all the youth of England are on fire, And silken dalliance in the wardrobe lies :

Now thrive the armourers, and honour's thought

Reigns solely in the breast of every man.

They sell the pasture now to buy the horse,

Following the mirror of all Christian kings,

With winged heels, as English Mercuries.

For now sits Expectation in the air,

And hides a sword from hilts unto the point

With crowns imperial, crowns and coronets,

Promis'd to Harry and his followers.

The French, advis'd by good intelligence

Of this most dreadful preparation,

Shake in their fear, and with pale policy

Seek to divert the English purposes.

O England ! Model to thy inward greatness,

Like little body with a mighty heart,

What might'st thou do, that honour would thee do,

Were all thy children kind and natural !

But see, thy fault France hath in thee found out,

A nest of hollow bosoms, which he fills

With treacherous crowns ; and three corrupted men; One, Richard Earl of Cambridge, and the second, Henry Lord Scroop of Masham, and the third, Sir Thomas Grey, knight, of Northumberland, Have, for the gilt of France, - $O$ guilt indeed ! Confirm'd conspiracy with fearful France ; And by their hands this grace of kings must die, If hell and treason hold their promises, Ere he take ship for France, and in Southampton.

Linger your patience on ; and we'll digest Th'abuse of distance ; force a play.

The sum is paid ; the traitors are agreed ; The king is set from London; and the scene Is now transported, gentles, to Southampton : 
There is the playhouse now, there must you sit ; And thence to France shall we convey you safe, And bring you back, charming the narrow seas To give you gentle pass; for if we may, We'll not offend one stomach with our play. But, till the king come forth and not till then, Unto Southampton do we shift our scene.

\section{The Arte of English Poesie, Book III, Chapter XVI. [XVII]}

Of the figures which we call Sensable, because they alter and affect the minde by alteration of sence, and first in single wordes.

The eare hauing receiued his due satisfaction by the auricular figures, now must the minde also be serued, with his naturall delight by figures sensible such as by alteration of intendmentes affect the courage, and geue a good liking to the conceit. And first, single words haue their sence and vnderstanding altered and figured many wayes, to wit, by transport, abuse, cross-naming, new naming, change of name. This will seeme very darke to you, vnlesse it be otherwise explaned more particularly : and first to Transport. [marginalia : Metaphora, or the Figure of transporte]. There is a kinde of wresting of a single word from his owne right signification, to another not so naturall, but yet of some affinitie or conueniencie with it, as to say, I cannot digest your unkinde words, for I cannot take them in good part : as the man of law said, I feele yo not, for I vnderstand not your case, because he had not his fee in his hand. Or as another said to a mouthy Aduocate, why barkest thou at me so sore? Or to call the top of a tree, or of a hill, the crowne of a tree or of a hill : for in deede crowne is the highest ornament of a Princes head, made like a close garland, or els the top of a 
mans head, where the haire windes about, and because such terme is not applied naturally to a tree, or to a hill, but / [ $\left.\mathrm{Xi}^{r}\right]$ is transported from a mans head to a hill or tree, therefore it is called by metaphore, or the figure of transport. 


\section{N O T E S}

'E.A.J. Honigmann, ed., Shakespeare and his Contemporaries, Essays in Comparison, Manchester, Manchester University Press, 1988, preface, p. ix.

${ }^{2} \mathrm{~K}$. Tetzeli von Rosador, «'Supernatural soliciting': Temptation and Imagination in Doctor Faustus and Macbeth», in Shakespeare and his Contemporaries, p. 44-5.

${ }^{3}$ There are of course some exceptions to this. See for instance the article by Daniel Javitch, «Poetry and Court Conduct : Puttenham's Arte of English Poesie in the Light of Castiglione's Cortegiano», Modern Language Notes, nº87, 1972, 2, p. 865-82.

${ }^{4}$ Frank Whigham, Ambition and Privilege, The Social Tropes of Elizabethan Courtesy Theory, Berkeley, Los Angeles, London, University of California Press, 1984.

${ }^{5}$ George Puttenham, The Arte of English Poesie, ed. Gladys Doidge Willcock and Alice Walker, Cambridge, Cambridge University Press, 1936, Book III, «Of Ornament», p. 224 : «When faith failes in Priestes sawes, / And Lords hestes are holden for lawes, / And robberie is tane for purchase, / And lechery for solace / Then shall the Realme of Albion / Be brought to great confusion. Where he might haue said as much in these words : when vice abounds, and vertue decayeth in Albion, then \&c.».

'Rushton, William Lowes, Shakespeare and 'The Arte of English Poesie', Liverpool, H. Young and Sons, 1909. Re-edited by AMS Press, New York, 1973.

'W.L. Rushton, p. 1.

${ }^{8}$ W. Shakespeare, Richard II, ed. Peter Ure, Arden $2^{\text {nd }}$ edition, London \& New York, Methuen, 1985 (1956), I.1-64-5. G. Puttenham, Arte, III, p. 259.

${ }^{9}$ The text I will be quoting throughout the article will be the 1936 Cambridge edition.

${ }^{10}$ Arte, III, p. 257.

"Shakespeare, William, Romeo and Juliet, ed. Brian Gibbons, Arden $2^{\text {nd }}$ edition, London \& New York, Routledge, 1991 (1980). The Merry Wives of Windsor, ed. T.W. Craik, Oxford \& New York, Oxford University Press, 1994 (1990).

${ }^{12}$ W.L. Rushton, p. 3.

'3raik's note specifies: «This is one of the 'sentences after the first collect' after the Litany in the Book of Common Prayer, 1559».

"See, on this subject, Gladys Willcock's comments, in her Introduction, p. lv-lvi. 
'ste, III, p. 251-2.

${ }^{16}$ Arte, Introduction, p. xciii.

${ }^{17}$ Arte, III, p. 251-3.

${ }^{18}$ Arte, Introduction, p. ci-cii.

${ }^{19}$ Arte, III, p. 180.

${ }^{20}$ King Henry IV, Part 2, ed. A.R. Humphreys, Arden $2^{\text {nd }}$ edition, London \& New York, Routledge, 1991 (1966).

${ }^{21}$ The First Part of King Henry VI, ed. Michael Hattaway, The New Cambridge Shakespeare, Cambridge, Cambridge University Press, 1990.

${ }^{22}$ King Henry V, ed. J.H. Walter, The Arden Shakespeare, $2^{\text {nd }}$ edition., London \& New York, Methuen, 1985 (1954). 